\title{
Preliminary considerations on the local educational project (pel), an example from the huancavelica region (peru)
}

\section{Consideraciones preliminares sobre el proyecto educativo local (pel), un ejemplo de la región huancavelica (perú)}

\author{
DOI: $10.46932 / \mathrm{sfjdv2n5-069}$
}

Received in: Oct 1st, 2021

Accepted in: Dec 30th, 2021

\section{Jose Yvan Vargas Bourguet \\ UNIVERSIDAD PERUANA UNIÓN}

Graduated from the Doctoral Program in Education at the Universidad Peruana Unión - UpeU

E-mail: josebourguet@upeu.edu.pe

\section{Raúl Eleazar Arias Sánchez \\ UNIVERSIDAD NACIONAL DE HUANCAVELICA}

Research professor at the Professional School of Economics of the Faculty of Business Sciences

E-mail: raul.arias@unh.edu.pe

\begin{abstract}
This article presents a general and normative overview of the Local Educational Project (PEL), its characteristics, structure, management and implementation as a local educational management instrument. In the same way, we point out some reflections in this regard and share a brief description of its development in the Huancavelica region (Peru).
\end{abstract}

Keywords: Education, planning, management

\section{RESUMEN}

El presente artículo presenta un panorama general y normativo sobre Proyecto Educativo Local (PEL), sus características, estructura, gestión y puesta en marcha como instrumento de gestión educativa local. De igual manera, señalamos algunas reflexiones al respecto y compartimos una breve descripción de su desarrollo en la región Huancavelica (Perú).

Palabras clave: Educación, planificación, Gestión

\section{INTRODUCTION}

The criterion used by the entire ELP is based on the guidelines of a broader sphere of government, since its articulation goes from one man to world international educational policy and that the world fully shares the ideal that "La educación para la ciudadanía mundial aspira a ser un factor de transformación, inculcando los conocimientos, las habilidades, los valores y las actitudes que los educandos necesitan para poder contribuir a un mundo más inclusivo, justo y pacífico.” (UNESCO, 2015 p. 15). Similarly, in our 
country, through the National Educational Project $(\mathrm{PEN})^{1}$ It is proposed that, considering educational planning and policy at government levels since, “...un sistema de planificación parte por preguntarse por los propósitos y las intencionalidades políticas y lee la realidad presente y las tendencias a futuro desde estas preocupaciones. Como herramienta de planificación, el PEN parte de una reflexión y declaración expresa de sus propósitos (educar ciudadanas y ciudadanos para alcanzar la promesa republicana)." (Consejo Nacional de Educación, 2020 p. 131). With the waste, the various educational work scenarios and strategic proposals for private and public actions may be achievable over time.

With this, the educational management would be able to position itself and “...busca dar respuesta a las necesidades reales y ser un ente motivador y dinamizador interno de las actividades educativas. Ya que el capital más importante lo constituyen los principales actores educativos que aúnan los esfuerzos tomando en cuenta los aspectos relevantes que influyen en la práctica del día a día, las expresiones el reconocimiento de su contexto y las principales situaciones a las que se enfrentan, es por ello que la gestión educativa, donde cada uno de los sujetos que constituyen el colectivo educativo pueda sentirse creador de su propia acción, tanto personal como profesional, dentro de un proyecto en común. Pues no olvidemos que el sujetó para constituirse como tal, requiere ser reconocido por el otro.” (Nina, 2018 p. 4).

This perspective points to the need for every province or district to be able to count on its PEL and make it a mechanism for exercising citizenship and conditions of freedom for its inhabitants while respecting their rights, since, "La principal razón para que una provincia o distrito tenga un proyecto educativo local es que el Estado tiene la obligación de brindar a los niños y niñas de todo el territorio nacional una educación gratuita de calidad que respete la diversidad cultural de nuestros pueblos. Esto es un derecho consagrado en la Constitución, la Ley General de Educación (LGE), el Proyecto Educativo Nacional (PEN), el Plan Nacional de Educación para Todos (PNEPT) y otras normas legales.” (Arana y Reynaga, 2009 p. 34)

\section{LEGAL BASE}

Article 194 of the Political Constitution of the State (Peru), modified by the Constitutional Reform Law, Law No. $30305^{2}$, in accordance with the provisions of Article II of the Preliminary Title of the Organic Law of Municipalities - Law No. 27972, establishes that the provincial municipalities and district are organs of Local Government, which enjoy political, economic and administrative autonomy in matters within their competence, such autonomy being based on the power to exercise administrative and administrative acts of government.

\footnotetext{
1 "Proyecto Educativo Nacional al 2036: el reto de la ciudadanía plena (2020)".

${ }^{2}$ https://leyes.congreso.gob.pe/Documentos/Leyes/30305.pdf
} 
The Organic Law of Municipalities - Law No. $27972^{3}$, in its article $82^{\circ}$, numeral 2) indicates that the municipalities, in matters of education, culture, sports and recreation, have as powers and functions shared with the national and regional governments, among others., that of designing, executing and evaluating the educational project of its jurisdiction, contributing to the educational and national policy with an intersectoral approach and action.

Article 40 of Law No. 27972, Organic Law of Municipalities establishes that "las ordenanzas de las municipalidades provinciales y distritales, en la materia de su competencia, son las normas de carácter general de mayor jerarquía en la estructura normativa municipal, por medio de las cuales se aprueba la organización interna, la regulación, administración y supervisión de los servicios públicos y las materias en las que la municipalidad tiene competencia normativa”.

The Local Educational Project (PEL) ${ }^{4}$ is a proposal for democratic and participatory management that allows the educational system to be planned in a concerted manner at the local level. Its purpose is the definition of short, medium and long-term objectives for the educational management of the district's localities, as well as the establishment of educational investment lines that guide budget resources and allow the management of private resources in the development of the educational policy of the locality seeking to link efforts for an educational change within a vision of development, which mobilizes the resources and potential of the population and strengthens the identities of the district within a process of integration, bearing in mind that a Plan Local Education, must be the product of a reflection exercise of the different social actors, about the problems and needs related to institutional or administrative pedagogical management, and must also respond to the problems and difficulties resulting from a participatory diagnosis, aimed at improvement. the quality of life of the population and the development of the capacities of the social groups involved. According to the indicated context, a local educational policy should be formulated as a process of building the future, formalized in a strategic plan that transcends the short, medium and long term.

\section{DEFINITION OF THE PEL}

According to the National Education Council (2020) the strategic orientation undoubtedly helps the achievement of objectives and goals for the good of education in our country, in this regard, "Todas las instancias de gestión educativa del Estado operan orientadas hacia la ciudadanía de modo profesional, estratégico, planificado para el mediano y largo plazo, haciendo uso intensivo de lo digital,

\footnotetext{
${ }^{3}$ https://www.mef.gob.pe/contenidos/presu_publ/capacita/programacion_formulacion_presupuestal2012/Anexos/ley279 72.pdf

${ }^{4}$ https://busquedas.elperuano.pe/normaslegales/aprueban-el-proyecto-educativo-local-pel-2015-2021-del-d-ordenanzano-460mc-1342522
} 
y articulado en todos sus niveles con otros sectores y actores de la comunidad local, nacional y global." (Consejo Nacional de Educación, 2020 p. 136). Now, and specifically, like any government action, the development of the PEL is based on a regulation, which is embodied in the Regulation of the General Education Law No. 28044 approved by the Ministry of Education on July 28, 2003.

For the specific case of our work, the TÍTULO III PROYECTO EDUCATIVO LOCAL, Article 51 defines the PEL as: “...el principal instrumento orientador de la gestión educativa local formulado por la Unidad de Gestión Educativa Local. Permite concretar acuerdos y compromisos recíprocos en torno a los objetivos planteados colectivamente. Se articula con el Plan de Desarrollo Local Concertado, con el Proyecto Educativo Regional y con el Proyecto Educativo Nacional.” (Reglamentación de la Ley General de Educación No 28044, 2003 p. 152).

In the same way, the TÍTULO IV LA COMUNIDAD EDUCATIVA, Article 52 indicates that, "La comunidad educativa está conformada por estudiantes, padres de familia, profesores, directivos, administrativos, ex alumnos y miembros de la comunidad local. Según las características de la Institución Educativa, sus representantes integran el Consejo Educativo Institucional y participan en la formulación y ejecución del Proyecto Educativo en lo que respectivamente les corresponda. La participación de los integrantes de la comunidad educativa se realiza mediante formas democráticas de asociación, a través de la elección libre, universal y secreta de sus representantes." (Reglamentación de la Ley General de Educación No 28044, 2003 p. 22). In this sense, the PEL is an instrument developed from the consensus of the members of an educational community in order to assume commitments and strategic actions. This set of actions can also be technically understood as a:...instrumento orientador de la gestión educativa de jerarquía local que se elabora en una cobertura distrital y provincial, que guarda una relación estrecha de objetivos y políticas estratégicas del Proyecto Educativo Nacional y el proyecto Educativo Regional con una proyección local. Se estructura en un organismo conformado por representantes institucionales de la localidad, contempla un plan programático de su infraestructura e implementación de sus ambientes y espacios, desarrolla capacidades en sus docentes y estudiantes, y también contextualiza y adecua sus contenidos a través de políticas y lineamientos." (Nina, 2018 p. 10)

Likewise, this document is of great importance because it raises the basis for carrying out contextual and real programming, which will serve students in their educational work. On the other hand, the PEL generates a scenario for solving needs and problems, taking advantage of the opportunities and strengths of the institutions involved, promoting pedagogical achievement and administrative coordination. As we can see, the PEL can be articulated from the strategic axes and objectives contained in the guidelines of the policies and regulations in force (Figure 1), likewise, it allows the prospective, purposeful and operational diagnostic components to achieve the objectives set. 
Figure 1.- Articulation of the PEL based on the regulations

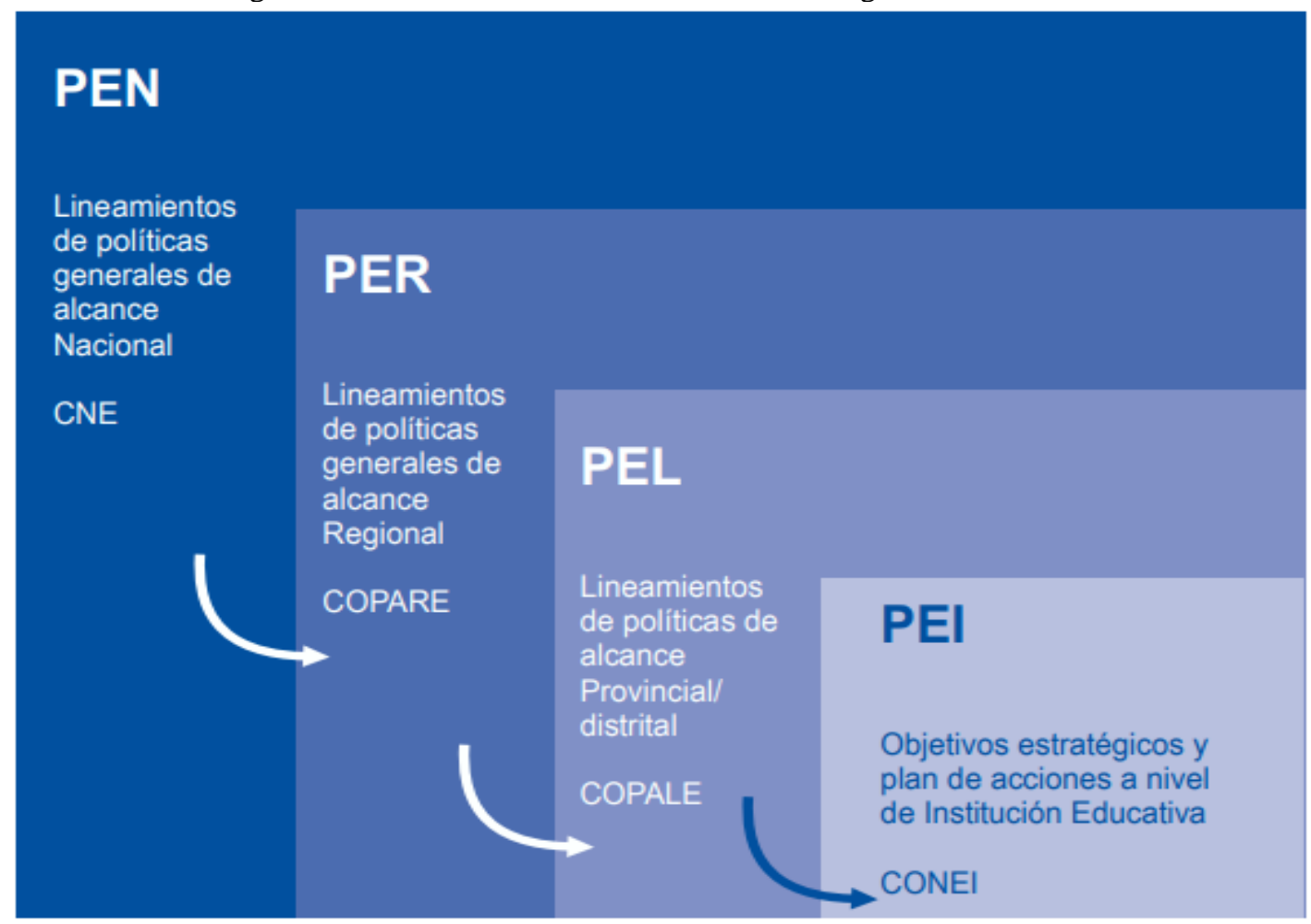

Note: Arana y Reynaga (2009 p. 38)

\section{IMPORTANCE OF MAKING A DIAGNOSIS}

To achieve everything described in previous lines, the PEL requires a real diagnosis of the situation and context, the TÍTULO III PROYECTO EDUCATIVO LOCAL, Article 52 indicates that the local educational diagnosis "Es componente del Proyecto Educativo Local. La Unidad de Gestión Educativa Local formula su diagnóstico educativo local, a partir de los lineamientos técnico-metodológicos establecidos por el Ministerio de Educación y las disposiciones específicas de la Dirección Regional de Educación. Contiene un inventario de los recursos públicos y privados, materiales y humanos disponibles en la localidad para la ejecución del Proyecto Educativo Local. Identifica aspectos críticos del funcionamiento del sistema educativo, situación de la matrícula escolar, situaciones de inequidad en la localidad, por motivo de idioma, etnia, género, creencia, opinión, condición económica u otra, situación de la infraestructura, y cumplimiento de las horas efectivas de trabajo escolar y aprendizaje de los alumnos. Recomienda medidas para enfrentarlos." (Reglamentación de la Ley General de Educación No 28044, 2003 p. 152)

Based on the experience of Nina (2018), this diagnosis should consider issues such as interculturality and diversity, democracy and citizenship, participation, equity and justice, research and a vision on ecology and sustainable development - ecological society - protection of the environment. This would ensure that the next strategic phase can deliver the expected result. Likewise, the diagnosis should start from an analysis of the situation and frequent trends. This work must contemplate the realization of 
an orderly database, identification of the main social actors, references of important activities and the identity recognition of the participating locality. This route can be based on many criteria, between particular experiences as well as governmental suggestions (Figure 2), in this sense, Arana and Reynaga (2009) designed a "Methodological Guide for the participatory formulation of the Local Educational Project", which is a source of consultation necessary to direct a PEL, and that contemplates fundamental aspects about the processes of construction of the agents in participatory processes, in this regard this would imply “...relacionar el proceso de construcción de los Proyectos Educativos Locales con los Proyectos Educativos Regionales y el Proyecto Educativo Nacional, y avanzar de esta manera en procesos de descentralización. Significa asumir roles específicos en los procesos participativos. No se trata de ninguna manera de suplantar el rol de garante de derechos que le toca a las municipalidades, a las regiones. Pero sí les toca a los docentes, padres de familia, organizaciones de base, estudiantes, aportar con propuestas socio-educativas e incidir con ellas en las políticas locales y regionales. Así vamos configurando el campo de las relaciones de poder, un poder que se construye participando desde la ciudadanía y en constante diálogo.” (Arana y Reynaga, 2009 p. 9)

Figure 2.- Government articulation of the PEI

\section{¿CÓMO SE ARTICULA A LAS POLITICAS NACIONALES, REGIONALES Y LOCALES?}

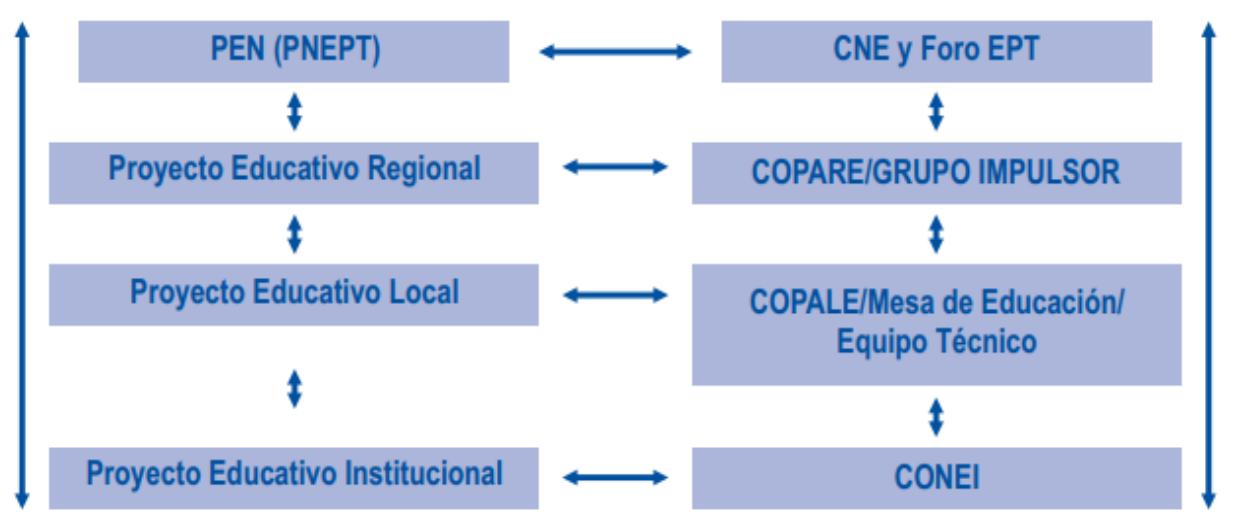

Note: Arana y Reynaga (2009 p. 39)

From this perspective, the reading of reality takes on a more holistic and structural analysis nuance, since the real evidence produced by the diagnosis allows a better result. In this sense, we must understand that this diagnosis must be understood as a "...lectura de la realidad, tiene como característica central, la de ser socialmente compartido puesto que cada persona, cada organización, cada institución tiene una particular lectura de la realidad, no tanto en lo que es identificación de problemas y necesidades sino principalmente en la jerarquización y priorización de ellas, puesto que en función de éstas es que se realiza la toma de decisiones. Hay que decir además que el diagnóstico no nos da un conocimiento absoluto de la realidad, es una interpretación que hacemos de la misma, expresa y se basa en un 
conocimiento crítico del contexto que se ha dado en el país, la región y el distrito, para ello es necesario, cuestionarlas y profundizarlas para que podamos actuar en el ámbito local.” (Arana y Reynaga, 2009 p. 40)

\section{PEL MANAGEMENT}

Now, once the diagnosis is achieved, the PEL must follow a strategic management process, the TÍTULO III PROYECTO EDUCATIVO LOCAL, Article 53 indicates in this regard that, "La Unidad de Gestión Educativa Local es responsable de convocar organizar y coordinar la participación del Consejo Participativo Local de Educación para la elaboración, seguimiento y evaluación del Proyecto Educativo Local, el que es aprobado por Resolución Directoral. Lo monitorea y evalúa, de acuerdo a indicadores establecidos, con la participación de las entidades de la sociedad civil, autoridades educativas de la Unidad de Gestión Educativa Local y del gobierno local. La convocatoria para su elaboración se hace por Resolución Directoral de la Unidad de Gestión Educativa Local." (Reglamentación de la Ley General de Educación No 28044, 2003 pp. 152-153)

As we can see, the Local Educational Management Unit (UGEL) is the entity in charge of coordinating the corresponding actions to direct the PEL, at the same time that it allows generating a scenario of need among its stakeholders to make a proposal of educational policies which a diagnosis of a socio-educational nature is supported.

\section{ABOUT THE PEL OF THE HUANCAVELICA REGION}

Regarding the Huancavelica region, despite searching for information in the various computer media and corresponding databases, we were unable to locate the complete document on the web. This draws our attention since, being a relevant instrument within the educational task, it is not hosted on any official website, much less is there any trace to catalog the information as a source of consultation for researchers or officials.

From what was reviewed, we note that the PEL of Huancavelica is registered within the general functions of the Local Educational Management Unit (UGEL) and this is manifested in Regional Ordinance No. 314-GOB.REG-HVCA / CR published on 05 of November 2015, which authority in CHAPTER III OF GENERAL FUNCTIONS, Article 5, numeral c), that the UGEL, among other things, must: “Diseñar, ejecutar y evaluar el Proyecto Educativo Local (PEL) y los programas de desarrollo de la cultura, ciencia y tecnología, deporte, recreación de su jurisdicción, en concordancia con los Proyectos Educativos Regionales y Nacionales y con el aporte, en lo que corresponda, de los gobiernos locales e instituciones de la Sociedad Civil.” (Ordenanza Regional N³14-GOB.REG-HVCA/CR, 2015 p. 6) 
Despite being an explicit function in the regulations, we could not find any document that evidences the work carried out, however, we did manage to "find" a publication on the Facebook social network made by the UGEL Huancavelica dated December 20, 2020, In the aforementioned, an invitation is made to the general population to be part of the Formulation Process of the Huancavelica Local Educational Project (Figure 3).

\section{Figura 3.- PEL Huancavelica}

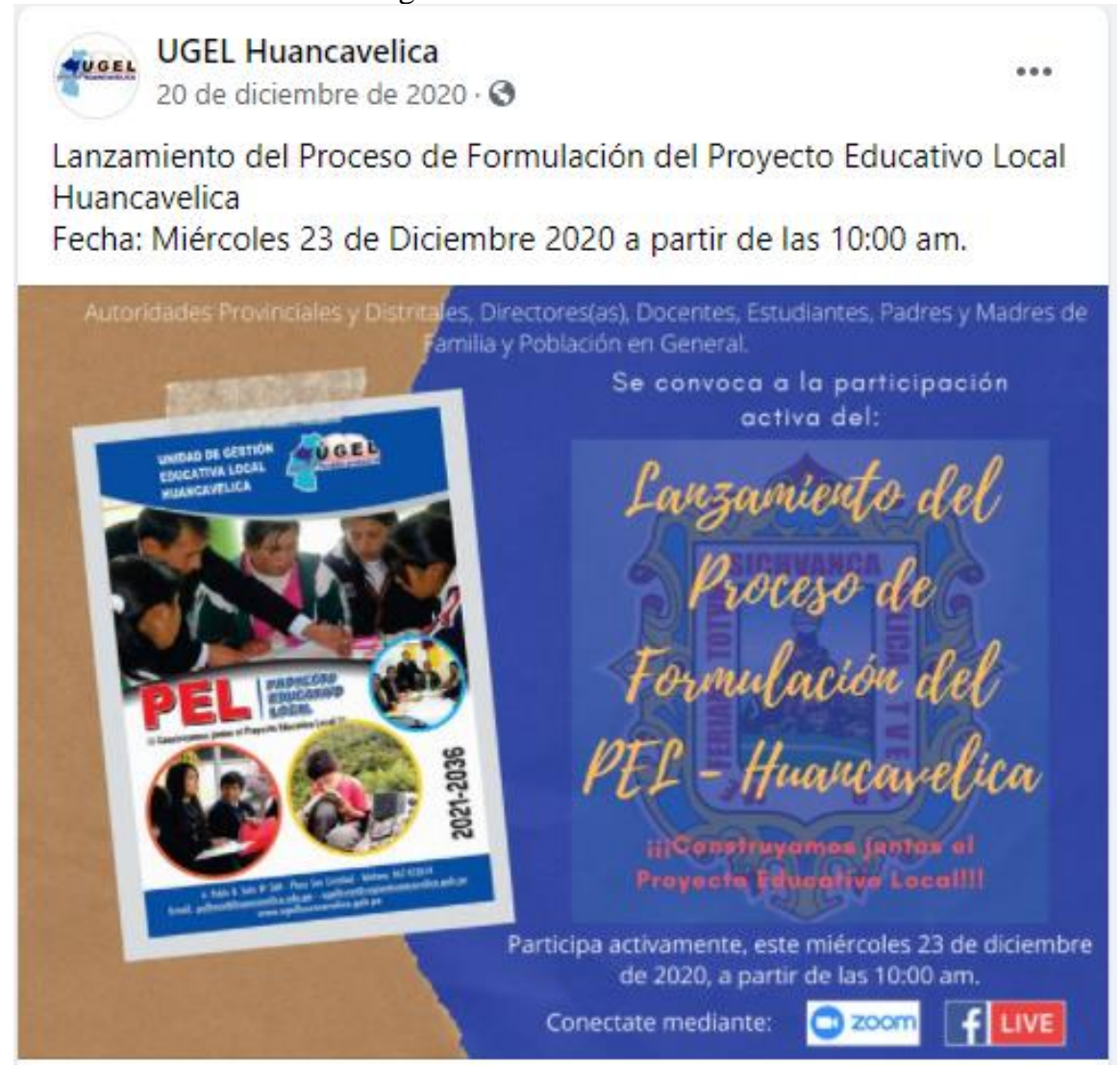

Note: Fanpage UGEL Huancavelica

These data were those that the network and the official information dissemination channels of the UGEL Huancavelica offered us. On the other hand, we must indicate that, recently, efforts are being developed for the mobilization and participation of the educational community as a whole for the update of the Regional Educational Project 2021-2036 (Figure 4). 


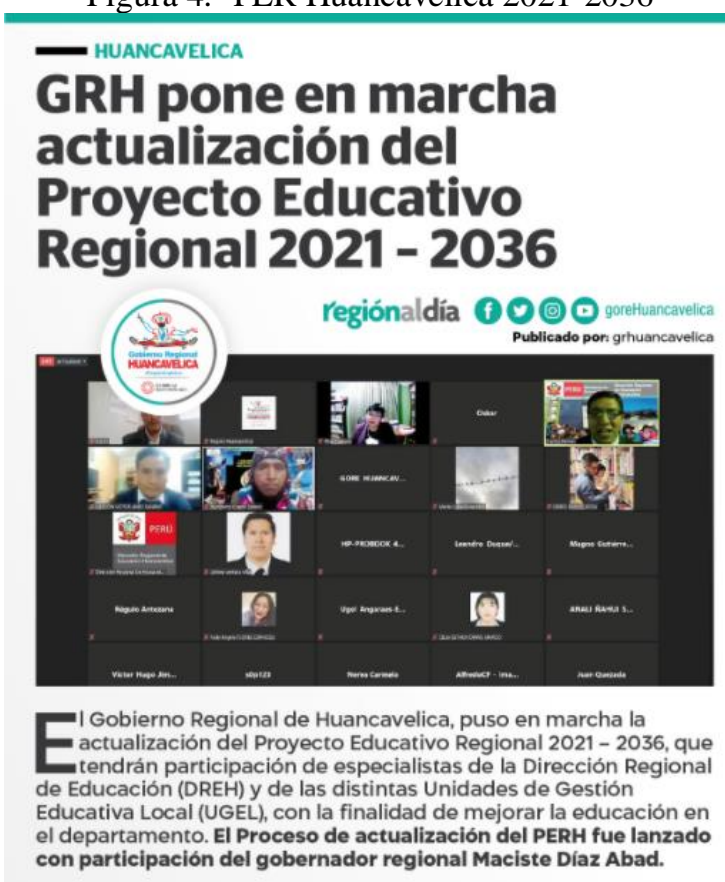

Note: Fanpage GORE Huancavelica

\section{CHALLENGES AND WORK TO BE DONE}

Therefore, we have found more references linked to regions or localities of the metropolitan Lima area and few experiences in the Andean region. We believe that this is due to several factors such as content updates, political decisions, budget or ignorance of the regulations and recently due to the pandemic.

The main challenge could be raised as the strategic management of the education budget to achieve this instrument, since citizen participation is always present, but the resources with which we approach not many times. Likewise, after COVID-19, the traditional approach with which we had been working must point or articulate the gesta of a new scenario within educational management, since although many of the PEL mentioned above were successful, today we face a new scenario of "normality" very different, linked to social networks, virtuality and technology.

Under this mosaic, we propose that there are innumerable challenges for the formulation and / or updating of the various ELPs, in the same way, for this to be developed successfully it is necessary that it starts from the national policy lines that are determined.

\section{CONCLUSIONS}

There are successful experiences in the design, formulation and evaluation of the PEL in our country promoted by local and district municipalities, some of them had the support of institutions (or third parties) through consultancies, others through the participation of their own technical team and some specialists, which indicates that this work requires a budget, which must be contemplated in the strategic 
guidelines of the governments. There is still a long way to go in terms of administrative and regulatory issues, since the needs or problems caused by COVID-19, so a good diagnosis and contextualization of real scenarios will serve to achieve the long-awaited educational quality and improvement of opportunities. between members of a community. 


\section{REFERENCES}

Arana, J. y Reynaga, H. (2009). Guía metodológica para la formulación participativa del Proyecto Educativo Local. Tarea Asociación de Publicaciones Educativas. https://tarea.org.pe/wpcontent/uploads/2020/04/JArana_HReynaga_Guia_Metodologica.pdf

Caycho, M., Joseph, J., Kerrigan, S., Mallqui, O. e Infante, O. (2009). Red Los Quinchayos Proyecto Educativo Local 2008-2021: distrito de Santo Domingo. Ministerio de Educación. http://repositorio.minedu.gob.pe/handle/20.500.12799/841

Consejo Nacional de Educación (2020). Proyecto Educativo Nacional al 2036: el reto de la ciudadanía plena. Recuperado el 31 de agosto de 2021 de https://www.cne.gob.pe/uploads/publicaciones/2020/proyecto-educativo-nacional-al-2036.pdf

Constitución Política del Perú [1993] Art. 194, 29 de diciembre de 1993. http://www.pcm.gob.pe/wpcontent/uploads/2013/09/Constitucion-Pol\%C3\%ADtica-del-Peru-1993.pdf

Ley $\quad N^{\circ}$ 27972, Ley Orgánica de Municipalidades (2003). https://www.mef.gob.pe/contenidos/presu_publ/capacita/programacion_formulacion_presupuestal2012/ Anexos/ley27972.pdf

Nina, R. (2018). La necesidad de un proyecto educativo local para La municipalidad distrital y la base técnico legal para garantizar la sostenibilidad de gestión con la educación básica regular del distrito de Pallpata, Espinar - Cusco, Región Cusco 2019. [Tesis de Maestría, Universidad Nacional San Agustín de Arequipa]. Repositorio institucional de la Universidad Nacional San Agustín de Arequipa http://repositorio.unsa.edu.pe/bitstream/handle/UNSA/7392/EDMniverv.pdf?sequence=1\&isAllowed=y

Ordenanza Regional N³14-GOB.REG-HVCA/CR (2015). Que aprueba la estructura orgánica y el Reglamento de Organización y Funciones (ROF), de la Unidad de Gestión Educativa Local de Acobamba, Castrovirreyna, Churcampa, Huancavelica, Surcubamba y Tayacaja. http://www.regionhuancavelica.gob.pe/descargas/upload/DOCUMENTOS\%20DE\%20GESTION/Regla mento\%20de\%20Organizacion\%20y\%20Funcion\%20-\%20ROF/735378_ROF-UGELHUANCAVELICA-2015.pdf

Reglamento de la Ley General de Educación No 28044 (2003). http://www.minedu.gob.pe/normatividad/reglamentos/EducacionCalidadyEquidad.pdf

UNESCO (2015). Educación para la ciudadanía mundial: temas y objetivos de aprendizaje. Recuperado el 31 de agosto de 2021 de http://www.iin.oea.org/pdf-iin/RH/docsinteres/2019/Resumen_Educacion_para_la_Ciudadania_UNESCO.pdf 